\title{
Pengaruh Model Pembelajaran Project Based Learning Terhadap Kemampuan Berpikir Kreatif IPA Kelas IV SD
}

\author{
Elok Maulidyah $^{1}$, M. Thamrin Hidayat ${ }^{2}$, Suharmono Kasiyun $^{3}$, Sri Hartatik $^{4}$ \\ Prodi PGSD Universitas Nahdlatul Ulama Surabaya ${ }^{1234}$ \\ elokmaulidyah98@gmail.com ${ }^{1}$,pmksthamrrin@gmail.com ${ }^{2}$, \\ suharmono@unusa.ac.id ${ }^{3}$, titax@unusa.ac.id ${ }^{4}$
}

\begin{abstract}
Abstrak
Penelitian ini bertujuan untuk meningkatkan kemampuan berpikir kreatif siswa pada mata pelajaran IPA materi gaya melalui penggunaan model pembelajaran Project Based Learning pada siswa kelas IV SD Labschool Unesa Lidah Wetan Surabaya. Pendekatan yang digunakan dalam penelitian ini adalah kuantitatif dengan menggunakan jenis desain Pre-Eksperimental model One-Group Pretest Posttest. Subjek penelitian ini adalah siswa kelas IV SD. Penelitian ini menggunakan satu kali pertemuan. Teknik pengumpulan data menggunakan tes berupa soal Pretest dan Posttest. Untuk menentukan perangkat pembelajaran sudah sesuai penelitian dilakukan validasi dua pakar kemudian dicari percentage of aggrement. Teknik analisis data yang digunakan adalah Shapiro-Wilk untuk mencari normalitas data, One Way Anova untuk mencari homogenitas data, serta uji statistik non parametrik berupa Wilcoxon Matched Pairs untuk mengetahui pengaruh model pembelajaran Project Based Learning terhadap kemampuan berpikir kreatif siswa. Hasil penelitian berupa Posttest yang dihitung dengan SPSS versi 16 menunjukkan output "Test Statistics" Asymp.Sig (2-tailed) bernilai 0,000 < 0,05, maka dapat disimpulkan bahwa hipotesis $1\left(\mathrm{H}_{1}\right)$ diterima artinya terdapat pengaruh model pembelajaran Project Based Learning terhadap peningkatan kemampuan berpikir kreatif siswa kelas IV SD Labschool Unesa Lidah Wetan Surabaya.
\end{abstract}

Kata Kunci : Project Based Learning, Berpikir Kreatif. 


\section{PENDAHULUAN}

Menurut Gagne (dalam Dahar, 2011: 2) belajar merupakan proses berupa pengalaman yang dapat mengubah perilaku individu dari waktu ke waktu. Belajar dapat terjadi di mana saja, kapan saja, dengan siapa saja, bagaimanapun caranya. Tidak harus saat kondisi formal saja, tetapi dapat dilakukan dalam segala kondisi termasuk kondisi informal maupun nonformal yang terpenting adanya kemajuan ke arah lebih baik

Menurut United Nations Environment Programme (dalam Suyono, 2016: 15) pembelajaran adalah segala bentuk pemahaman dan pengetahuan dari sebuah pengalaman individu. Dalam proses pembelajaran terutama di sekolah, guru perlu memberikan kebebasan belajar pada siswa untuk mengembangkan kemampuan berpikir kreatif melalui ide dan pemikiran yang di miliki. Kemampuan berpikir kreatif dipandang penting karena akan membentuk kebiasaan yang baik serta membuat peserta didik memiliki banyak cara dalam menyelesaikan berbagai persoalan dengan pemikiran berbagai macam.

Bermacam upaya untuk meningkatkan kemampuan berpikir kreatif siswa dalam pembelajaran salah satunya dapat melalui model pembelajaran yang diterapkan oleh guru. Menurut Isro'atun (2019: 27) model pembelajaran adalah gambaran dari sebuah pembelajaran yang terstruktur untuk membantu siswa membangun dan mencapai tujuan yang sesuai. Selain itu menurut Ngalimun (2017: 38) model pembelajaran adalah suatu model belajar yang tersusun terdiri dari prosedur, pengalaman belajar serta tujuan dari belajar tersebut. Model pembelajaran biasanya memuat tentang deskripsi lingkungan belajar, pendekatan, manfaat, materi pembelajaran, serta media pembelajaran.

Terdapat banyak model pembelajaran yang dapat diterapkan dalam proses pembelajaran untuk meningkatkan kemampuan berpikir kreatif. Salah satunya yaitu model pembelajaran Project Based Learning. Menurut Thomas (dalam Ibnu Badar al-Tabany, 2014: 42) Project Based Learning ialah pendekatan pembelajaran yang terencana, kreatif serta menekankan kepada pembelajaran yang bersumber dari keadaan nyata. Project Based Learning berfokus pada ciri dan prinsip yang bertujuan agar siswa terlibat aktif dalam pembelajaran, mengelola tugas dan waktu belajar, 
memecahkan masalah, mengintergrasikan pembelajaran yang sempurna, menghasilkan suatu produk atau karya berdasarkan hasil pemikiran kreatif.

Menurut Reigeluth (dalam Suprihatiningrum, 2017: 37) hasil belajar adalah kinerja yang diindikasikan sebagai suatu kemampuan yang telah diperoleh. Hasil belajar merupakan tujuan akhir dilaksanakannya kegiatan pembelajaran di sekolah. Hasil belajar dapat ditingkatkan melalui usaha sadar yang dilakukan secara sistematis mengarah kepada perubahan yang positif.

Salah satu mata pelajaran yang berhubungan dengan kemampuan berpikir kreatif dan kognitif siswa ialah mata pelajaran Ilmu Pengetahuan Alam. Menurut The Harper Encyclopedia of Science (dalam Subiyanto, 1990: 4) Ilmu Pengetahuan adalah kumpulan dari pengetahuan dan pendapat pendukung yang tersusun dan ditunjang oleh bukti-bukti ilmiah. Di dalam mata pelajaran IPA terdapat pemahaman konsep-konsep IPA yang bermanfaat serta dapat diterapkan dalam kehidupan seharihari yang berhubungan dengan cara kerja, cara berpikir serta cara memecahkan masalah.

Kenyataan yang ada saat ini hasil belajar siswa kelas IV dalam mempelajari mata pelajaran IPA termasuk cukup baik. Siswa juga memiliki rasa ingin tahu terhadap materi-materi baru, akan tetapi pembelajaran masih di dominasi oleh guru. Selain itu belum adanya penilaian tersendiri untuk melihat ada tidaknya pengaruh suatu model pembelajaran terhadap pemikiran kreatif siswa jika diterapkan model pembelajaran tersebut. Fenomena tersebut menjadi dasar keingintahuan peneliti apakah terdapat pengaruh jika diterapkan model pembelajaran Project Based Learning terhadap kemampuan berpikir kreatif siswa. Tujuan dari penelitian ini yaitu untuk mengetahui ada atau tidaknya pengaruh model pembelajaran Project Based Learning terhadap kemampuan berpikir kreatif siswa kelas IV pada materi gaya mata pelajaran IPA di SD Labschool Unesa Lidah Wetan Surabaya.

\section{METODE PENELITIAN}

Sebelum peneiliti mengadakan penelitian, terlebih dahulu peneliti menyiapkan perangkat pembelajaran seperti menyusun silabus, rencana pelaksanaan pembelajaran, bahan ajar berupa lembar kegiatan siswa kelompok, kisi-kisi soal, soal pretest posttest serta rubrik penilaian pretest posttest kemampuan berpikir kreatif. 
Perangkat tersebut di validasi oleh pakar untuk melihat kevalidan data. Hasil validasi perangkat pembelajaran dapat dianalisis menggunakan teknik deskriptif kuantitatif dengan cara menghitung rata-rata skor penilaian validator. Selanjutnya nilai rata-rata disesuaikan dengan Tabel berikut.

Tabel 1 Kategori Validitas Perangkat

\begin{tabular}{ll}
\hline Interval Nilai & Kategori Valid \\
\hline $3,25-4,0$ & Sangat valid \\
\hline $2,75-3,24$ & Valid \\
\hline $1,75-2,74$ & Kurang valid \\
\hline $1,0-1,74$ & Sangat tidak valid \\
\hline
\end{tabular}

Ratumanan dan Laurens (dalam Utami, 2019)

Selanjutnya dilakukan uji reliabilitas yang mengacu pada perhitungan Percentage of Agreement. Rumusnya sebagai berikut:

$$
\mathrm{R}=\left[1-\frac{A-B}{A+B}\right]
$$

Borich (dalam Utami, 2019)

Huruf $\mathrm{R}$ adalah reliabilitas perangkat. Huruf $\mathrm{A}$ adalah frekuensi aspek tingkah laku yang teramati oleh pengamat dengan frekuensi tinggi, sedangkan huruf $\mathrm{B}$ adalah frekuensi aspek tingkah laku yang teramati oleh pengamat dengan frekuensi rendah. Penelitian ini menggunakan pendekatan kuantitatif dengan jenis desain PreEksperimental model One-Group Pretest-Posttest. Rumusnya sebagai berikut:

$$
\mathrm{O}_{1} \mathrm{X} \mathrm{O}_{2}
$$

Huruf $\mathrm{O}_{1}$ adalah hasil dari tes berupa soal pretest. Sedangkan huruf $\mathrm{X}$ adalah perlakuan yang diberikan dan dilihat pengaruhnya dalam eksperimen tersebut, perlakuan yang dimaksud berupa model pembelajaran berbasis proyek. Dan huruf $\mathrm{O}_{2}$ adalah hasil dari tes berupa soal posttest yang dilakukan setelah model pembelajaran berbasis proyek diberikan. Pengaruh perlakuan $\mathrm{X}$ dapat diketahui dengan 
membandingkan antara hasil pretest $\mathrm{O}_{1}$ dan hasil posttest $\mathrm{O}_{2}$ dalam situasi yang terkontrol.

Penelitian ini dilakukan di Sekolah Dasar Labschool Unesa Lidah Wetan Surabaya Jl. Citra Raya Lidah Wetan, Kec. Lakarsantri, Surabaya. Pengambilan data awal penelitian dilakukan pada November 2019. Sedangkan pengambilan data penelitian ini dilakukan sehari pada Maret 2020.

Populasi dalam penelitian ini adalah seluruh siswa kelas IV SD Labschool Unesa Lidah Wetan Surabaya yang berjumlah 20 siswa dengan rincian 7 siswa perempuan dan 13 siswa laki-laki. Sedangkan sampel yang digunakan ialah sampel jenuh dari anggota populasi dikarenakan jumlah populasi penelitian $<100$ orang.

Penelitian ini menggunakan teknik pengumpulan data berupa tes untuk mengukur ada tidaknya atau besar kecilnya pengaruh Project Based Learning terhadap kemampuan berpikir kreatif siswa. Tes merupakan teknik pengumpulan data melalui pertanyaan yang membutuhkan jawaban atau tanggapan. Fungsi tes yakni, untuk mengukur kemampuan seseorang dalam bidang tertentu. Instrumen yang terdapat dalam penelitian ini yaitu bentuk tes yang diberikan ialah tes essai berupa pretest dan posttest, terdiri dari 1 soal uraian mengenai materi gaya yang terdapat dalam mata pelajaran IPA kelas IV SD.

Teknik analisis data yang digunakan dalam penelitian ini adalah data kuantitatif. Uji normalitas data menggunakan Shapiro-Wilk yang terdapat dalam SPSS versi 16. Data dapat dikatakan berdistribusi normal apabila hasil tes $>0,05$, namun jika hasil tes $<0,05$ maka data tidak berdistribusi normal. Kemudian data di uji homogenitas menggunakan One Way Anova, taraf signifikasi yang digunakan apabila sig > 0,05 maka data dinilai homogen, sedangkan apabila sig $<0,05$ maka data dinilai tidak homogen. Selanjutnya uji hipotesis menggunakan uji statistik non parametrik dengan uji wilcoxon matched pairs.

\section{HASIL DAN PEMBAHASAN}

\section{Hasil}

\section{Hasil Validitas dan Reliabilitas Silabus}

Silabus merupakan suatu bentuk penjabaran dari standar kompetensi dan kompetensi dasar ke materi pokok pembahasan, kegiatan, indikator, pencapaian 
kompetensi. Menurut Maolani \& Cahyo (dalam Mabruroh, 2019: 33) validitas adalah kualitas yang menunjukkan kesesuaian antara alat pengukur dengan tujuan yang diukur. Sedangkan reliabilitas adalah kualitas yang menunjukkan kestabilan pengukuran yang dilakukan. Validasi silabus mata pelajaran IPA pada materi gaya telah divalidasi oleh 2 validator. Hasil validasi silabus mendapat rata-rata sebesar 3,5. Menurut Ratumanan dan Laurens (dalam Utami, 2019) perangkat pembelajaran dikatakan sangat valid apabila hasil rata-rata penilaian validator berada dalam interval 3,25 - 4,0. Maka silabus ini termasuk dalam kategori sangat valid. Kemudian dilanjutkan dengan uji reliabilitas silabus sebagai berikut:

$$
\begin{aligned}
& \mathrm{R}=1-\left[\frac{A-B}{A+B}\right] \times 100 \% \\
& \mathrm{R}=1-\left[\frac{4-3}{4+3}\right] \times 100 \% \\
& \mathrm{R}=1-\left[\frac{1}{7}\right] \times 100 \% \\
& \mathrm{R}=1-[0,14] \times 100 \% \\
& \mathrm{R}=86 \%
\end{aligned}
$$

Borich (dalam Utami, 2019)

Uji reliabilitas menunjukkan hasil akhir sebesar 86\%. Menurut Borich (dalam Utami, 2019:242) instrumen penilaian yang menggunakan rumus percentage of agreement dikatakan reliabel apabila hasilnya $\geq 75 \%$. Maka silabus model pembelajaran Project Based Learning pada mata pelajaran IPA materi gaya dikatakan Reliabel. Pemvalidasian ini bertujuan untuk menelaah perangkat pembelajaran sebelum di ujicobakan. Hasil validasi baik karena penyusunannya telah disesuaikan dengan Kurikulum 2013.

\section{Hasil Validitas dan Reliabilitas RPP}

Rencana Pelaksanaan Pembelajaran adalah penjabaran dari silabus berupa kegiatan pembelajaran yang dilaksanakan dalam proses belajar mengajar serta waktu pelaksanaan dan biasanya untuk satu kali pertemuan. RPP mata pelajaran IPA pada materi gaya telah divalidasi oleh 2 validator. Hasil validasi RPP mendapat rata-rata sebesar 3,6 dan termasuk dalam kategori sangat valid. Selain itu RPP juga telah dilakukan uji reliabilitas dan menunjukkan hasil akhir sebesar 86\% sehingga RPP model pembelajaran Project Based Learning pada mata pelajaran IPA materi gaya dikatakan reliabel. Pemvalidasian ini bertujuan untuk menelaah perangkat 
pembelajaran sebelum di ujicobakan. Hasil validasi RPP yang digunakan peneliti telah sesuai dengan aturan Permendikbud Nomor 22 Tahun 2016 tentang Standar Pendidikan Dasar dan Menengah. RPP telah sesuai dengan petunjuk yang memuat aspek penilaian dan dinilai oleh dua orang pakar meliputi: 1) identitas mata pelajaran, 2) pertemuan indikator, 3) perumusan tujuan pembelajaran, 4) pemilihan materi pelajaran, 5) penilaian sumber belajar, 6) model pembelajaran yang digunakan ialah Project Based Learning, 7) skenario pembelajaran, 8) rancangan penilaian yang disesuaikan dengan fase model pembelajaran Project Based Learning.

\section{Hasil Validitas dan Reliabilitas LKS}

Lembar Kerja Siswa adalah bentuk panduan untuk membantu siswa saat kegiatan pembelajaran, dalam hal ini pembelajaran menggunakan model pembelajaran Project Based Learning. LKS mata pelajaran IPA pada materi gaya telah divalidasi oleh 2 validator. Hasil validasi LKS mendapat rata-rata sebesar 3,4 dan termasuk dalam kategori sangat valid. Selain itu LKS juga telah dilakukan uji reliabilitas dan menunjukkan hasil akhir sebesar $86 \%$ sehingga LKS model pembelajaran Project Based Learning pada mata pelajaran IPA materi gaya dikatakan reliabel. Pemvalidasian ini bertujuan untuk menelaah perangkat pembelajaran sebelum di ujicobakan. Hasil validasi LKS telah sesuai dengan aturan Permendikbud Nomor 8 Tahun 2016 tentang Buku yang digunakan oleh Satuan Pendidikan.

\section{Hasil Validitas dan Reliabilitas Pretest dan Posttest}

Pretest adalah soal yang diberikan kepada siswa sebelum diberikan materi dan model pembelajaran sedangkan Posttest adalah soal yang diberikan kepada siswa sesudah diberikan sebuah materi maupun model pembelajaran. Pretest dan Posttest ini telah divalidasi oleh 2 validator. Hasil validasi Pretest dan Posttest mendapat rata-rata sebesar 3,4 dan termasuk dalam kategori sangat valid. Selain itu RPP juga telah dilakukan uji reliabilitas dan menunjukkan hasil akhir sebesar $86 \%$ sehingga soal Pretest dan Posttest model pembelajaran Project Based Learning pada mata pelajaran IPA materi gaya dikatakan reliabel. Pemvalidasian ini bertujuan untuk menelaah perangkat pembelajaran sebelum di ujicobakan. Hasil validasi soal Pretest dan Posttest telah disesuaikan dengan petunjuk Permendikbud Nomor 104 Tahun 
2014 tentang Penilaian Hasil Belajar oleh Pendidik pada Pendidikan Dasar dan Pendidikan Menengah.

\section{Pembahasan}

\section{Penerapan Model Pembelajaran Project Based Learning Terhadap Kemampuan Berpikir Kreatif Siswa}

Penelitian ini menggunakan uji coba satu kelas sebelum diberi perlakuan dan sesudah diberi perlakuan. Dari data berpikir kreatif siswa sebelum diberi perlakuan, pada saat pembelajaran guru belum memiliki penilaian khusus tentang berpikir kreatif pada mata pelajaran IPA sehingga diperoleh hasil Pretest berpikir kreatif siswa yang diukur menggunakan tes berupa soal uraian sejumlah 1 butir. Untuk menilai hasil Pretest berpikir kreatif siswa dapat menggunakan rubrik penilaian yang poinnya antara 0-4 dan nilai itu diubah menjadi penilaian yang poinnya 1-100 untuk dimasukkan dalam perhitungan SPSS.

Kemudian siswa diberikan perlakuan berupa model pembelajaran Project Based Learning. Setelah diberikan pembelajaran dengan menggunakan model pembelajaran Project Based Learning, siswa diukur kembali berpikir kreatifnya menggunakan tes berupa soal uraian yang sama persis dengan soal Pretest. Penilaian juga sama dengan soal Pretest dengan menggunakan rubrik penilaian yang poinnya antara 0-4 dan nilai itu diubah menjadi penilaian 1-100 untuk dimasukkan dalam perhitungan SPSS versi 16.

Hasil Pretest siswa dihitung dan mendapatkan rata-rata sebesar 68,75. Berdasarkan data hasil berpikir kreatif siswa sebelum dan sesudah diberi perlakuan di atas, kemudian diuji lanjutan dengan menggunakan SPSS versi 16 sebagai berikut: 
Uji Normalitas

Hasil uji normalitas seperti pada Tabel di bawah ini:

\section{Tabel 2 Hasil Uji Normalitas}

Tests of Normality

\begin{tabular}{lrrrrrrr}
\hline & \multicolumn{3}{c}{ Kolmogorov-Smirnov $^{\mathrm{a}}$} & \multicolumn{3}{c}{ Shapiro-Wilk } \\
\hline & Statistic & df & Sig. & Statistic & df & Sig. \\
\hline Hasil sebelum & .163 & 20 & .169 & .906 & 20 & .053 \\
\hline Hasil sesudah & .372 & 20 & .000 & .701 & 20 & .000 \\
\hline
\end{tabular}

Lilliefors Significance Correction

rmalitas ini menggunakan acuan Shapiro-Wilk karena subyek penelitian kecil berjumlah 20 siswa. Data dapat dikatakan berdistribusi normal apabila hasil tes $>0,05$, namun jika hasil tes $<0,05$ maka data tidak berdistribusi normal. Berdasarkan pada perhitungan SPSS, nilai signifikan hasil Pretest pada kolom Shapiro-Wilk sebesar 0,053 dan hasil Posttest sebesar 0,000. Dapat disimpulkan bahwa data yang diperoleh ialah data yang tidak berdistribusi normal secara keseluruhan.

Uji Homogenitas

Hasil uji homogenitas seperti pada Tabel di bawah ini:

Tabel 3 Hasil Uji Homogenitas

Test of Homogeneity of Variances

Hasil penelitian

\begin{tabular}{cccc}
\hline Levene Statistic & df1 & df2 & Sig. \\
\hline 20.344 & 1 & 38 & .000
\end{tabular}


Uji homogenitas ini menggunakan One-Way Anova. Data dikatakan homogen apabila sig > 0,05, sedangkan apabila data memiliki sig $<0,05$ maka data dinilai tidak homogen. Berdasarkan hasil perhitungan di atas, didapatkan nilai signifikan 0,000 pada Test of Homogenity of Variancesse dan disimpulkan bahwa variabel Project Based Learning terhadap kemampuan berpikir kreatif siswa tidak homogen.

\section{Pengaruh Penerapan Model Pembelajaran Project Based Learning Terhadap Kemampuan Berpikir Kreatif Siswa}

Untuk melihat ada tidaknya pengaruh penerapan model pembelajaran Project Based Learning terhadap kemampuan berpikir kreatif siswa, dilakukan uji hipotesis menggunakan uji statistik non parametrik dengan analisis uji Wilcoxon Matched Pairs, hasilnya terdapat dalam Tabel di bawah ini:

Tabel 4 Hasil Uji Hipotesis

\begin{tabular}{lr}
\hline \multicolumn{2}{c}{ Test Statistics $^{\mathrm{b}}$} \\
\hline $\mathrm{K}$ & $-3.952^{\mathrm{a}}$ \\
\hline Ksymp. Sig. (2-tailed) & .000 \\
\hline Based on negative ranks. & \\
Wilcoxon Signed Ranks Test &
\end{tabular}

Pada penelitian ini, sebelum diterapkannya model pembelajaran Project Based Learning kemampuan berpikir kreatif siswa diuji dengan menggunakan soal Pretest dan mendapatkan rata-rata sebesar 68,75 yang artinya kemampuan berpikir kreatif siswa masih rendah, sehingga peneliti memberikan perlakuan berupa model pembelajaran Project Based Learning yang bertujuan untuk meningkatkan kemampuan berpikir kreatif siswa. Setelah diberikan model pembelajaran Project Based Learning dalam 
pembelajaran kemudian dihitung hasil Posttest siswa dan rata-rata yang didapat sebesar 92,25.

Berdasarkan Tabel 8, dapat diketahui bahwa hasil output Test Statistics diketahui bahwa Asymp.Sig (2-tailed) bernilai 0,000 yang artinya sesuai dengan uji hipotesis awal bahwa terdapat pengaruh model pembelajaran Project Based Learning terhadap kemampuan berpikir kreatif pada mata pelajaran IPA kelas IV materi Gaya di SD Labschool Unesa Lidah Wetan Surabaya. Teori yang mendukung Project Based Learning untuk meningkatkan kemampuan berpikir kreatif ialah Teori Belajar Konstruktivisme Jean Piaget dan Vygotsky (dalam Ratnasari, 2016: 14-16).

Adapula penelitian yang relevan dengan penelitian ini seperti penelitian milik Mabruroh (2019: 60) yang menunjukkan adanya pengaruh model pembelajaran berbasis proyek terhadap kemampuan berpikir kritis siswa kelas VI SD Negeri Margorejo VI Surabaya. Ada pula penelitian milik Tama (2019:78) yang menyatakan bahwa terdapat pengaruh signifikan model pembelajaran Project Based Learning terhadap kemampuan berpikir kreatif peserta didik kelas VII semester gasal SMP Negeri 22 Bandar Lampung tahun pelajaran 2018/2019.

\section{SIMPULAN}

Berdasarkan penelitian yang telah dilakukan dapat dilihat hasil Pretest mendapatkan rata-rata sebesar 68,75 dan hasil Posttest mendapat rata-rata sebesar 92,25. Terdapat selisih peningkatan nilai siswa yang cukup besar antara sebelum dan sesudah diterapkan model pembelajaran Project Based Learning dalam pembelajaran. Selain itu pembelajaran dengan menggunakan model pembelajaran Project Based Learning dapat meningkatkan kemampuan berpikir kreatif siswa kelas IV SD Labschool Unesa Lidah Wetan Surabaya. 


\section{DAFTAR PUSTAKA}

Dahar, Ratna Wilis. (2011). Teori-Teori Belajar dan Pembelajaran. Jakarta: Erlangga.

Ibnu Badar al-Tabany, Trianto. (2014). Mendesain Model Pembelajaran Inovatif, Progresif, Dan Kontekstual : Konsep, Landasan, Dan Implementasinya Pada Kurikulum 2013 (Kurikulum Tematik Integratif/TKI). Jakarta: Prenadamedia Group.

Isro'atun., Rosmala, Amelia. (2019). Model-Model Pembelajaran Matematika. Jakarta: PT Bumi Aksara.

Mabruroh, Milda. (2019). Pengaruh Model Pembelajaran Project Based Learning Terhadap Kemampuan Berpikir Kritis Siswa Kelas VI SD pada Materi Energi Listrik Di SD Negeri Margorejo VI Surabaya. Skripsi. Surabaya: Universitas Nahdlatul Ulama Surabaya.

Ngalimun. (2017). Strategi Pembelajaran. Yogyakarta: Dua Satria Offet.

Permendikbud Nomor 104 Tahun 2014 tentang Penilaian Hasil Belajar oleh Pendidik pada Pendidikan Dasar dan Pendidikan Menengah.

Permendikbud Nomor 8 Tahun 2016 tentang Buku yang digunakan oleh Satuan Pendidikan.

Permendikbud Nomor 22 Tahun 2016 tentang Standar Pendidikan Dasar dan Menengah.

Ratnasari. (2016). Pengaruh Pembelajaran Berbasis Proyek Berbantuan Lembar Kerja Siswa Pada Materi Koloid Terhadap Kemampuan Berpikir Kreatif Siswa. Skripsi. Semarang: Universitas Negeri Semarang.

Subiyanto. (1990). Strategi Belajar-Mengajar Ilmu Pengetahuan Alam. Malang: IKIP Malang.

Suprihatiningrum, Jamil. (2017). Strategi Pembelajaran: Teori \& Aplikasi. Jogjakarta: Ar-Ruzz Media.

Suyono, Hariyanto. (2011). Belajar dan Pembelajaran: Teori dan Konsep Pembelajaran. Bandung: PT Remaja Rosdakarya.

Tama, Hanifah Nurmira. (2019). Pengaruh Model Project Based Learning (PJBL) Terhadap Kemampuan Komunikasi Sains Dan Berpikir Kreatif Peserta Didik Kelas VII SMPN 22 Bandar Lampung. Skripsi. Bandar Lampung: Universitas Lampung. 
Utami, Septiana Dwi., Efendi, Ismail., Dewi, Ika Nurani., Ramdani, Agus., Rohyani, Immy Suci. (2019). Validitas Perangkat Pembelajaran Etnoekologi Masyarakat Suku Sasak Kawasan Taman Nasional Gunung Rinjani. Jurnal Penelitian Pendidikan IPA, 5 (2), 240-247. Mataram: Institut Keguruan dan Ilmu Pendidikan Mataram. 